\title{
THE BIBLIOMETRIC ANALYSIS OF TOP 100 CITED ARTICLES IN ENVIRONMENTAL EPIDEMIOLOGY
}

\section{Ayse Gulsen Teker ${ }^{1}$}

${ }^{1}$ Dokuz Eylül University, School of Medicine Department of Public Health, Epidemiology Subsection Balcova-Izmir, Turkey

Address for Correspondence: Dr.Ayse Gulsen Teker, , E-mail: agulsenteker@hotmail.com Received: 06.01.2021; Accepted: 22.02.2021; Available Online Date: 04.03.2021

(C) Copyright 2020 by Dokuz Eylül University, Institute of Health Sciences - Available online at https://dergipark.org.tr/tr/pub/jbachs

Cite this article as: Gulsen Teker A. The bibliometric analysis of top 100 cited articles in environmental epidemiology. J Basic Clin Health Sci 2021; 1: 54- 59.

\begin{abstract}
Purpose: The bibliometric analysis of the 100 most cited articles -the Top 100- (T100) in the field of environmental epidemiology from the Web of Science is used to determine the quantitative characteristics. The aim of this study is to determine the quantitative properties of the 100 most cited articles -the Top 100(T100) in the field of environmental epidemiology and to contribute to the determination of research trends and predictions of developments in this field.

Methods: In this bibliometric study the ISI Web of Science database has been detected to find T100 in the field of environmental epidemiology. The term [Epidemi* AND environment $\left.{ }^{\star}\right]$ was used to search for articles. T100 was listed and analyzed using bibliometrics.

Results: Top 100 articles were published in 59 journals and cited between 697 and 4991 times. T100 was made by 15 different countries and T100 articles originated $20 \%$ from USA. The most common topics are chronic diseases, mental diseases, infectious diseases, toxins, cancers, nutrition and physical activity, air pollution and fetal development, respectively. The subject of the most cited publication was geneenvironment interactions in depression.

Conclusion: Popular research topics and trends in environmental epidemiology have been presented in this study. This bibliometric analysis of the T100 in environmental epidemiology provided insight into current developments in this area.
\end{abstract}

Keywords: epidemiology, environment, bibliometrics

\section{INTRODUCTION}

Epidemiology is the science that examines the distribution and determinants of health and disease states in a population ${ }^{1}$. Environmental epidemiology is concerned with environmental determinants of the distribution of health and disease-related conditions. In other words, it is used to investigate the effects of physical, biological and chemical factors in the 
external environment on human health. Environmental epidemiology aims to clarify the relationship between physical, biological and chemical factors and human health by examining specific populations or individuals exposed to different environments. In the expression environmental, it includes large geographical areas as well as small personal areas. Environmental epidemiology examines the effects of the environment on human health from chronic diseases to infectious diseases, from mental diseases to intoxications and it is multidisciplinary ${ }^{2,3}$. Environmental epidemiology examines the effects of factors such as water, food, air pollution, radiation and climate change on public health ${ }^{4}$. In addition, popular science topics such as human behavior, inequalities and epigenetics are also in the field of environmental epidemiology because sociocultural environment, income status, and welfare level directly or indirectly affect human and community health ${ }^{5}$.

Bibliometric methods are used to provide quantitative analysis of written publications. It consists of bibliographic examination of scientific studies and selection and evaluation of highly cited publications ${ }^{6}$. This method of analysis is useful for examining the trends of scientific research over time. Reviewing the most frequently cited articles helps researchers to identify specific areas of expertise that may require further research. In addition, the focus of the most influential articles and work areas can be assessed by analyzing the most frequently cited articles ${ }^{7}$.

There are many current bibliometric studies in the field of epidemiology $y^{7-11}$. However, a bibliometric study examining publications in the field of environmental epidemiology has not yet been conducted.

Therefore, the aim of this study is to determine the quantitative properties of the 100 most cited articles the Top 100- (T100) in the field of environmental epidemiology through the Web of Science and to contribute to the determination of research trends and predictions of developments in this field.

\section{METHODS}

\section{Research Strategy}

Articles were found through the ISI Web of Science (Institute for Scientific Information, Thomson
Scientific, Philadelphia, Pennsylvania) database. T100 was searched using the terms [Epidemi* AND environment*]. 49,555 articles were found using these terms. Among these articles, the 100 articles most cited were selected. Each article was included in the study after careful consideration of the abstract. No time filtering was performed when searching for articles. All articles published until July 2019 were included in the research. While searching the articles, no language filtering was performed, but it was observed that all 100 articles were written in English. Both original studies and reviews were included in the study. The article excluded if: 1) the subject of the article was outside the field of environmental epidemiology 2) the type of article was conference abstract, editorial or letter. The articles found were coded according to the following parameters: title, journal, type of publication (original research or review), year of publication, number of citations, country of publication, country of the institution where the first author works (accepted as the country of article conducted) and subject of the article.

\section{Statistical Analysis}

The data of the research was recorded and analyzed in Microsoft Excel spreadsheets. Citation numbers, interquartile range (IQR) and median values were used.

\section{RESULTS}

T100 has been published by a total of 59 journals. Lancet ranked first with 8 articles; Nature and Clinical Microbiology Reviews were second with 6 articles; Science and Gastroenterology ranked third with 4 articles. The list of articles that the T100 was published is presented in Table 1. While 48 of the articles were original researches, 52 were reviews. 70 of the T100 were published in journals originating from the United States of America (USA), 20 from England, 3 from the Netherlands and 1 from Switzerland and New Zealand.

The countries where the first authors of the T100 work are presented in Table 2. Accordingly, the first authors of the T100 are from 15 different countries and USA ranked first with 54 articles.

The total number of citations of the T100 was 145,904 . The number of citations of the T100 ranged between 697 and 4991 (median: 1148 and IQR: 
Table: 1. List of Journals Published T100

\begin{tabular}{|c|c|c|c|c|c|}
\hline Journal & $\begin{array}{l}\text { No. of } \\
\text { Articles }\end{array}$ & $\begin{array}{l}\text { Total No. of } \\
\text { Citations }\end{array}$ & Journal & of Articles & $\begin{array}{l}\text { Total No. of } \\
\text { Citations }\end{array}$ \\
\hline Acta Neuropathologica & 1 & 761 & Journal of Affective Disorders & 1 & 933 \\
\hline $\begin{array}{l}\text { American Journal of Clinical } \\
\text { Nutrition }\end{array}$ & 3 & 2685 & $\begin{array}{l}\text { Journal of Epidemiology and } \\
\text { Community Health }\end{array}$ & 1 & 1227 \\
\hline $\begin{array}{l}\text { American Journal of } \\
\text { Preventive Medicine } \\
\end{array}$ & 1 & 770 & $\begin{array}{l}\text { Journal of the American College of } \\
\text { Cardiology }\end{array}$ & 2 & 3382 \\
\hline $\begin{array}{l}\text { American Journal of } \\
\text { Psychiatry }\end{array}$ & 2 & 2276 & Lancet & 8 & 12119 \\
\hline $\begin{array}{l}\text { Annals of the New York } \\
\text { Academy of Sciences }\end{array}$ & 1 & 722 & Lancet Infectious Diseases & 1 & 811 \\
\hline $\begin{array}{l}\text { Annual Review of } \\
\text { Neuroscience }\end{array}$ & 1 & 751 & Mayo Clinic Proceedings & 1 & 1345 \\
\hline $\begin{array}{l}\text { Annual Review of } \\
\text { Phytopathology }\end{array}$ & 1 & 905 & $\begin{array}{l}\text { Medicine \& Science in Sports \& } \\
\text { Exercise }\end{array}$ & 1 & 2601 \\
\hline $\begin{array}{l}\text { Annual Review of Public } \\
\text { Health }\end{array}$ & 3 & 4178 & Molecular Biotechnology & 1 & 1578 \\
\hline Archives of General Psychiatry & 3 & 3059 & Nature & 6 & 17613 \\
\hline Biointerphases & 1 & 1185 & Nature Medicine & 1 & 810 \\
\hline British Medical Bulletin & 1 & 1408 & Nature Neuroscience & 1 & 2373 \\
\hline British Medical Journal & 1 & 737 & Nature Reviews Cancer & 2 & 1715 \\
\hline $\begin{array}{l}\text { Bulletin of the World Health } \\
\text { Organization }\end{array}$ & 1 & 1005 & Nature Reviews Endocrinology & 1 & 829 \\
\hline $\begin{array}{l}\text { Cancer Epidemiology } \\
\text { Biomarkers \& Prevention }\end{array}$ & 1 & 730 & Nature Reviews Genetics & 1 & 1419 \\
\hline Circulation & 1 & 1361 & Nature Reviews Neurology & 1 & 710 \\
\hline Clinical Microbiology Reviews & 6 & 5200 & Nature Reviews Neuroscience & 1 & 797 \\
\hline $\begin{array}{l}\text { Comparative Immunology } \\
\text { Microbiology and Infectious } \\
\text { Diseases }\end{array}$ & 1 & 1358 & New England Journal of Medicine & 2 & 3280 \\
\hline Diabetes & 1 & 896 & Obesity & 1 & 746 \\
\hline Ecology Letters & 1 & 697 & Pediatrics & 2 & 3458 \\
\hline Endocrine Reviews & 3 & 3805 & Physiological Reviews & 1 & 1201 \\
\hline $\begin{array}{l}\text { Environmental Health } \\
\text { Perspectives }\end{array}$ & 2 & 5615 & Plos Genetics & 1 & 1016 \\
\hline Environmental Toxicology & 1 & 820 & Plos One & 1 & 717 \\
\hline European Respiratory Journal & 1 & 2205 & $\begin{array}{l}\text { Proceedings of the National Academy } \\
\text { of Sciences of the USA }\end{array}$ & 2 & 4252 \\
\hline Gastroenterology & 4 & 7702 & Psychological Medicine & 3 & 4837 \\
\hline Human Reproduction & 1 & 1349 & Quality of Life Research & 1 & 1509 \\
\hline $\begin{array}{l}\text { Infection Control And Hospital } \\
\text { Epidemiology }\end{array}$ & 1 & 1933 & Science & 4 & 9690 \\
\hline $\begin{array}{l}\text { International Archives of } \\
\text { Occupational and Environment }\end{array}$ & 1 & 813 & Social Science \& Medicine & 1 & 1839 \\
\hline $\begin{array}{l}\text { International Journal for } \\
\text { Parasitology }\end{array}$ & 1 & 1736 & Sports Medicine & 1 & 765 \\
\hline $\begin{array}{l}\text { International Journal of } \\
\text { Epidemiology }\end{array}$ & 1 & 1136 & $\begin{array}{l}\text { Toxicology And Applied } \\
\text { Pharmacology }\end{array}$ & 1 & 1041 \\
\hline $\begin{array}{l}\text { Jama-Journal of the American } \\
\text { Medical Association }\end{array}$ & 2 & 1676 & & & \\
\hline
\end{tabular}


865.25). T100 was published between 1991 and 2015. Table 3 presents the T100 according to publication years.

When we look at T100 topics, it is determined that chronic diseases and environmental risk factors was the most common topic. The subject of the 12 of the 20 articles written on this topic were obesity; 2 were related to diabetes mellitus; 2 were related to coronary artery disease and 3 article were related to asthma, congenital heart disease and Chron's Disease and inflammatory bowel disease. Mental diseases were the second most common topic of the T100. The subject of the 4 articles were depression and environmental risk factors; 3 articles were related to Alzheimer's disease; 3 articles schizophrenia, 2 articles autism, 2 articles psychosis, 1 article behavior disorders and 1 article examined the subject of anxiety disorders and environmental factors. The subject of 1 article on this topic was the geneenvironment relationship in mental disorders. The topic infectious diseases was listed as third in the T100. The subject of environmental risk factors and environmental prevention methods in the occurance and spread of infectious diseases was addressed in 14 articles in this topic. Toxins have been the subject of 8 articles in the T100: each of the subjects Endocrine-Distrupting Chemicals; lead, mercury, cadmium, genotoxins and neurotoxins were discussed in 1 article. The relationship between environmental risk factors and cancer has been the subject of 8 articles. Nutrition and physical activity were examined in the context of both environmental factors and environmental interventions in 8 articles. Air pollution has been the subject of 7 articles. In this topic 3 articles were related to the relationship between air pollution and chronic diseases. In 1 article, air pollution was related to premature mortality and in 3 articles, the effects of nano particles on human health were investigated. Environmental effects on fetal development and effects on the health of the fetus were included in 4 articles. In the remaining 14 articles; quality of life, epigenetic, microbiome, biofilms, environmental inequalities, income inequalities, oral health, neighborhood, disability, epigenetics, burden of disease and mendelian randomization were examined in terms of health effects of environmental factors. The T100 topics are summarized in Table 4.

\section{DISCUSSION}

In this bibliometric study, the T100 on environmental epidemiology searched trough ISI Web of Science. T100 was published in 59 journals.

The search was performed without using any language or time filter but it was observed that T100 was published in English. The years T100 was published were found between 1991-2015.

The T100 has been conducted by a total of 15 countries. All of these countries except Cuba are high-income countries. However, more than $80 \%$ of the world's population lives in low, lower middle and upper middle income countries. This may be due to

Table 2. T100 According to the Region of the First Author's Institution

\begin{tabular}{lcc}
\hline Regions & No. of Articles & Total No. of Citations \\
\hline USA & 54 & 80890 \\
England & 10 & 17736 \\
Australia & 9 & 11757 \\
Holland & 6 & 5906 \\
Germany & 4 & 4729 \\
Canada & 3 & 4917 \\
France & 3 & 2613 \\
Switzerland & 3 & 3353 \\
Sweden & 2 & 4541 \\
Cuba & 1 & 811 \\
Denmark & 1 & 869 \\
Italy & 1 & 1016 \\
New Zealand & 1 & 2205 \\
Norway & 1 & 1578 \\
Scotland & 1 & 2306 \\
\hline
\end{tabular}

T100: Top 100 Most-Cited Articles

lack of resources, lack of capacity, different health priorities or language problems in these countries. In addition, the journals indexed in the ISI Web of Science have strict criteria, and therefore publications in low, lower middle, upper middle income countries may not be included in the T100.

The journal with the highest number of the T100 articles is the Lancet; the largest number of citations belongs to articles published in the Nature. The most cited article in the T100 (4991 times) is a longitudinal 
Table 3. T100 Categorised by the Publication Year

\begin{tabular}{lcc}
\hline Publication & No. of Articles & Total No. of Citations \\
Year & 1 & \\
\hline 1991 & 1 & 905 \\
1992 & 1 & 765 \\
1994 & 2 & 1839 \\
1995 & 1 & 3768 \\
1996 & 1 & 1155 \\
1997 & 4 & 1081 \\
1998 & 1 & 7227 \\
1999 & 8 & 959 \\
2000 & 8 & 16139 \\
2001 & 6 & 10882 \\
2002 & 5 & 10126 \\
2003 & 9 & 9252 \\
2004 & 9 & 12775 \\
2005 & 5 & 13800 \\
2006 & 5 & 9041 \\
2007 & 9 & 12942 \\
2008 & 5 & 5390 \\
2009 & 5 & 5740 \\
2010 & 5 & 5815 \\
2011 & 6 & 3939 \\
2012 & 4 & 10403 \\
2013 & 560 \\
2015 & 5 & 1001 \\
\hline $1100:-$ & 1 &
\end{tabular}

T100: Top 100 Most-Cited Articles

Tablo 4. Topic Distrubition of Top100

\begin{tabular}{lcc}
\hline Topic & $\begin{array}{c}\text { No. of } \\
\text { Articles }\end{array}$ & $\begin{array}{c}\text { Total No. of } \\
\text { Citations }\end{array}$ \\
\hline Chronic Diseases & 20 & 36109 \\
Mental Diseases & 17 & 23558 \\
Infectious Diseases & 14 & 14790 \\
Toxins & 8 & 10758 \\
Cancers & 8 & 12043 \\
Nutrition And Physical Activity & 8 & 9023 \\
Air Pollution & 7 & 10541 \\
Fetal Development & 4 & 5123 \\
Other Topics & 14 & 23959 \\
\hline T100: Top 100 Most-Cited Articles & \multicolumn{2}{|}{}
\end{tabular}

study published in the Science in 2003 and is concerned with gene-environment interactions in depression ${ }^{12}$. According to this bibliometric analysis, the most common topic in the T100 in the field of environmental epidemiology is mental diseases after chronic diseases. If we examine the most frequently cited articles within the T100 by topics; The most cited article on chronic diseases (4780 times) was published in the Nature in 2006. The subject is the relationship between obesity and intestinal microbioma ${ }^{13}$. The most cited article on infectious diseases (2205 times) was published in the 1995 in the European Respiratory Journal on asthma and environmental risk factors ${ }^{14}$. The most cited article on toxins ( 2373 times) is about the relationship between chronic pesticide use and Parkinson's disease, and was published in the Nature Neuroscience in $2000^{15}$. On the topic of cancers most cited article published in the Gastroenterology in 2005 examining environmental risk factors in hepatocellular carcinoma cited 3479 times $^{16}$. The article published in the Medicine \& Science in Sports \& Exercise in 2000 and cited 2601 times, the subject of the article is environmental determinants that affect the physical activity status of children and adolescents ${ }^{17}$. On the topic of air pollution the most cited article (4474 times) published in the Environmental Health Perspectives in 2005 and the subject of the article is nanoparticles and their effects on health ${ }^{18}$. The article published in the British Medical Bulletin, published in 2001, examines the relationship between environmental conditions in the fetal period and the possibility that the fetus will have diabetes in later years has been cited 1408 times $^{19}$. This bibliometric research revealed a broad spectrum of environmental epidemiology. Many subjects have been included in the T100 under very different topics. As a matter of fact, bibliometric analysis - especially citation analysis - is recommended for the determination of research trends, finding focus topics for new researches or compiling researches in a specific field ${ }^{20,21}$.

Although this research provides useful information on identifying the most influential publications in the field of environmental epidemiology, setting out research trends, and setting focus for new research, there are some limitations. First of all, the only search engine used was ISI Web of Science. There are strict criteria for participation in the ISI Web of Science. Another is that the time filter is not used when searcing articles, and that older articles have a greater chance of being cited.

In conclusion, popular research topics and trends in environmental epidemiology have been presented in this study. This bibliometric analysis of the T100 in environmental epidemiology provided insight into current developments in this area.

Conflict of Interest: There are no conflicts of interest in connection with this paper. 
Financial Disclosure: This research received no specific grant from any funding agency, commercial entity or not-for-profit organization.

Ethics statement: Ethical approval is not required for this research because it contains information freely available in the public domain.

Peer-review: Externally peer-reviewed.

\section{REFERENCES}

1. Baker D, Nieuwenhuysen M.J. Environmental epidemiology, study methods and application. Oxford: Oxford University Press; 2008.

2. Kreis IA, Busby A, Leonardi G, Meara J, Murray $V$, editors. Essentials of Environmental Epidemiology for Health Protection: A handbook for field professionals. Oxford University Press; 2013

3. Committee on Environmental Epidemiology NR. Environmental Epidemiology, Volume 2: Use of the Gray Literature and Other Data in Environmental Epidemiology. Washington: National Academies Press; 1997.

4. Wilkinson $\mathrm{P}$, editor. Environmental epidemiology. Maidenhead, Berkshire, England: Open University Press; 2006.

5. Braveman P, Egerter S, Williams DR. The Social Determinants of Health: Coming of Age. Annu Rev Public Health. 2011;21;32(1):381-98.

6. Ellegaard O, Wallin JA. The bibliometric analysis of scholarly production: How great is the impact? Scientometrics. 2015;105(3):1809-31.

7. Liu L, Li Y, Zhang G-S, Wu J-Y, Majithia S, Tham Y-C, et al. Top 100 cited articles in ophthalmic epidemiology between 2006 and 2016. Int J Ophthalmol. 2018;11(12):1994-8.

8. Schisterman EF, Swanson CW, Lu Y-L, Mumford SL. The changing face of epidemiology: gender disparities in citations? Epidemiol Camb Mass. 2017;28(2):159-68.

9. Cheng WF, Shen ZA, Zhao DX, Li DW, Shang YR. Bibliometric analysis of scientific articles on epidemiological study of burns in China. Chin J Burns. 2017;20;33(4):233-7.

10. Allen LN, Fox N, Ambrose A. Quantifying research output on poverty and noncommunicable disease behavioural risk factors in low-income and lower middle-income countries: a bibliometric analysis. BMJ Open. 2017;7(11):e014715.
11. Müller AM, Maher CA, Vandelanotte $C$, Hingle $M$, Middelweerd A, Lopez ML, et al. Physical Activity, Sedentary Behavior, and Diet-Related eHealth and mHealth Research: Bibliometric Analysis. J Med Internet Res. 2018;20(4):e122.

12. Caspi A, Sugden K, Moffitt TE, Taylor A, Craig IW, Harrington $\mathrm{H}$, et al. Influence of Life Stress on Depression: Moderation by a Polymorphism in the 5-HTT Gene. 2003;301:5.

13. Turnbaugh PJ, Ley RE, Mahowald MA, Magrini V, Mardis ER, Gordon JI. An obesity-associated gut microbiome with increased capacity for energy harvest. Nature. 2006;444(7122):102731.

14. Asher MI, Keil U, Anderson HR, Beasley R, Crane J, Martinez F, et al. International study of asthma and allergies in childhood (ISAAC): rationale and methods. Eur Respir J. 1995;8(3):483-91.

15. Betarbet R, Sherer TB, MacKenzie G, GarciaOsuna M, Panov AV, Greenamyre JT. Chronic systemic pesticide exposure reproduces features of Parkinson's disease. Nat Neurosci. 2000;3(12):1301-6

16. El-Serag HB, Rudolph KL. Hepatocellular Carcinoma: Epidemiology and Molecular Carcinogenesis. Gastroenterology. 2007;132(7):2557-76.

17. Sallis JF, Prochaska JJ, Taylor WC. A review of correlates of physical activity of children and adolescents: Med Sci Sports Exerc. 2000;96375.

18. Oberdörster G, Oberdörster E, Oberdörster J. Nanotoxicology: An Emerging Discipline Evolving from Studies of Ultrafine Particles. Environ Health Perspect. 2005;113(7):823-39.

19. Hales CN, Barker DJP. The thrifty phenotype hypothesis. Br Med Bull. 2001;60(1):5-20.

20. Turki $H$. Citation analysis is also useful to assess the eligibility of biomedical research works for inclusion in living systematic reviews. J Clin Epidemiol. 2018;97:124-5.

21. Van Raan AFJ. The use of bibliometric analysis in research performance assessment and monitoring ofinterdisciplinary scientific developments. Schwerpunktthema. 2003;1(17):20-29. 